\title{
Penggunaan Bahan Restorasi di Rumah Sakit Gigi dan Mulut Fakultas Kedokteran Gigi Universitas Prof. Dr. Moestopo (Beragama)/RSGM FKG UPDM (B) pada Tahun 2014-2016
}

\section{Sari Dewiyani, ${ }^{1}$ Ika Puspitasari ${ }^{2}$}

\author{
${ }^{1}$ Departemen Konservasi Fakultas Kedokteran Gigi Universitas Prof. Dr. Moestopo \\ (Beragama), Jakarta, Indonesia \\ ${ }^{2}$ Program Studi Departemen Konservasi Fakultas Kedokteran Gigi Universitas Prof. Dr. \\ Moestopo (Beragama), Jakarta, Indonesia \\ Email: sari.drg@gmail.com \\ Disubmisi: 8 Juni 2021; direvisi: 6 September 2021; diterima: 14 September 2021
}

\begin{abstract}
Dental caries results in destruction of hard structure of teeth that causes demineralization of calcified tissue associated with destruction of organic tissue due to microorganisms and fermented carbohydrates. Dental caries can be treated with tooth resroration. There are different types of materials for dental restorations, as follows: amalgam, composite resins, and glass ionomer cement (GIC). This study was aimed to obtain the usage of restoration materials at Rumah Sakit Gigi dan Mulut Fakultas Kedokteran Gigi Universitas Prof. Dr. Moestopo (Beragama) [RSGM FKG UPDM (B)] Jakarta from 2014 to 2016. This was a descriptive and retrospective study. Samples were obtained by using random sampling technique. There were 1322 cases categorized based on age, sex, and location of restoration. Amalgam restoration was the most common in patients aged 17-25 years and in females. Most teeth at posterior region were treated with amalgam restoration (72\%). In conclusion, the most common cases were amalgam restoration, aged 17-25 years, female, and posterior location of restoration.
\end{abstract}

Keywords: resin composite; glass ionomer cement (GIC); amalgam; dental caries

\begin{abstract}
Abstrak: Karies gigi adalah suatu penyakit infeksi yang merusak struktur keras gigi sehingga menyebabkan demineralisasi jaringan terkalsifikasi, disertai kerusakan jaringan organiknya yang disebabkan oleh aksi mikroorganisme dan karbohidrat yang dapat di fermentasi. Salah satu cara penanganan karies gigi ialah dengan cara merestorasi gigi menggunakan bahan restorasi gigi. Bahan restorasi yang sering digunakan saat ini ialah amalgam, resin komposit, dan glass ionomer cement (GIC). Penelitian ini bertujuan untuk mengetahui distribusi frekuensi penggunaan bahan restorasi di Rumah Sakit Gigi dan Mulut Fakultas Kedokteran Gigi Universitas Prof. Dr. Moestopo (Beragama)/RSGM FKG UPDM (B) Jakarta pada tahun 20142016. Jenis penelitian ialah deskriptif dengan pendekatan retrospektif. Pengambilan sampel menggunakan teknik random sampling. Hasil penelitian mendapatkan 1322 kasus yang dikategorikan berdasarkan usia, jenis kelamin, dan lokasi restorasi. Perawatan dengan amalgam lebih sering dilakukan oleh pasien yang berusia 17-25 tahun dan berjenis kelamin perempuan. Regio posterior merupakan regio gigi yang paling banyak mendapatkan restorasi dengan amalgam. Simpulan penelitian ini ialah penggunaan bahan restorasi terbanyak ialah restorasi amalgam dengan kelompok usia terbanyak 17-25 tahun, jenis kelamin perempuan, dan lokasi restorasi pada posterior $(72 \%)$.
\end{abstract}

Kata kunci: resin komposit; glass ionomer cement (GIC); amalgam; karies gigi 


\section{PENDAHULUAN}

Kesehatan gigi dan mulut merupakan salah satu faktor penting bagi kesehatan tubuh manusia. Peningkatan pengetahuan, kesadaran, kemauan, dan kemampuan dalam melaksanakan hidup sehat merupakan faktor pencegahan terjadinya penyakit. Sampai saat ini di negara Indonesia paling banyak ditemukan adanya masalah kesehatan gigi dan mulut yaitu kasus penyakit periodontal dan karies gigi dengan prevalensi yang cukup tinggi di berbagai daerah.

Hasil Riset Kesehatan Dasar (Riskesdas) Nasional tahun 2007 dan 2013 memperlihatkan prevalensi masalah kesehatan gigi dan mulut di Indonesia mengalami peningkatan dari $23,2 \%$ menjadi $25,9 \%$. Proposi tertinggi yang mempunyai masalah kesehatan gigi dan mulut berada pada kelompok usia produktif yaitu 35-44 tahun sebesar 30,5\% dan usia 45-54 tahun sebesar $31,9 \%$. Berdasarkan kelompok jenis kelamin, jenis kelamin perempuan memiliki masalah tertinggi pada kesehatan gigi dan mulut sebesar $27,1 \%$ dibandingkan laki-laki sebesar 24,8\%. ${ }^{1}$ Faktor usia dan jenis kelamin merupakan hal yang penting dalam mempelajari suatu masalah kesehatan karena berkaitan dengan daya tahan tubuh, ancaman terhadap kesehatan, dan kebiasaan hidup serta pada beberapa penyakit terdapat perbedaan frekuensi antara laki-laki dan perempuan., ${ }^{2,3}$

Karies gigi adalah suatu penyakit infeksi yang merusak struktur keras gigi dan menyebabkan demineralisasi jaringan terkalsifikasi disertai kerusakan jaringan organiknya diakibatkan oleh aksi mikroorganisme dan karbohidrat yang dapat di fermentasi. Salah satu cara pencegahan terjadinya karies gigi ialah dengan cara merestorasi gigi menggunakan bahan restorasi gigi. ${ }^{4,5}$ Bahan restorasi yang sering digunakan saat ini ialah amalgam, resin komposit, dan glass ionomer cement (GIC). ${ }^{6}$ Bahan restorasi ini memiliki kelebihan dan kekurangan sesuai dengan komposisi dan sifat masing-masing bahan. $^{7}$ Penelitian Tyas $^{8}$ di Australia melaporkan bahwa jenis restorasi yang paling banyak digunakan ialah restorasi resin komposit $(55 \%)$ dan resorasi amalgam $(28 \%)$.

Resin komposit (RK) merupakan bahan restorasi estetik yang dapat digunakan pada gigi anterior dan posterior yang berukuran kecil hingga sedang tanpa tekanan kunyah yang besar. Bahan RK memiliki kemampuan mengiritasi pulpa yang cukup rendah dan tidak dapat diletakkan dengan baik pada kavitas yang terkontaminasi saliva dan darah, serta memiliki ketahanan terhadap celah mikro yang terbentuk di antara bahan restorasi dengan struktur gigi. ${ }^{9,10}$ Glass ionomer cement (GIC) merupakan bahan restorasi yang sewarna gigi dan dapat digunakan untuk kavitas dengan tekanan kunyah rendah. Bahan GIC memiliki struktur seperti resin komposit dengan estetik yang baik, tetapi warnanya lebih opak dibandingkan dengan warna email gigi asli. 9,10 Amalgam merupakan bahan restorasi yang tidak sewarna dengan gigi sehingga digunakan pada gigi posterior. Amalgam juga merupakan bahan tambalan yang tidak mudah pecah, tahan lama, dan dapat menahan beban kunyah yang besar, serta harganya relatif murah..$^{9,10}$

Berdasarkan paparan mengenai masih tingginya prevalensi karies gigi dan berbagai pilihan bahan restorasi gigi maka penulis tertarik untuk mengetahui penggunaan bahan restorasi di Rumah Sakit Gigi dan Mulut Fakultas Kedokteran Gigi Universitas Prof. Dr. Moestopo (Beragama) [RSGM FKG UPDM (B)] Jakarta pada tahun 20142016 ditinjau dari jenis kelamin, usia, dan lokasi gigi yang direstorasi.

\section{METODE PENELITIAN}

Penelitian ini dilakukan pada bulan Juli 2017 di RSGM FKG UPDM (B). Jenis penelitian ialah deskriptif dengan menggunakan pendekatan retrospektif. Populasi penelitian ialah seluruh rekam medik pasien di Bagian Klinik Konservasi RSGM FKG UPDM (B) tahun 2014-2016. Sampel ialah sebagian data rekam medik pasien yang dianggap mewakili seluruh populasi dan memenuhi kriteria inklusi dan eksklusi.

Kriteria inklusi dari sampel penelitian ini ialah sebagian data status rekam medik pasien berisi keterangan bahan restorasi RK, 
GIC, dan amalgam pada tahun 2014-2016 yang memiliki informasi tentang jenis kelamin, usia dan lokasi gigi yang direstorasi sedangkan yang termasuk kriteria eksklusi ialah rekam medik pasien yang tidak jelas keterangannya, baik mengenai karakteristik maupun pilihan restorasi, rekam medik rusak yang menyebabkan kesulitan membaca data, dan rekam medik yang tidak lengkap.

Teknik pengumpulan data dalam penelitian ini dilakukan dengan metode simple random sampling. Subjek penelitian ini berupa data sekunder yang diperoleh dari kartu status kesehatan pasien yang berobat di RSGM FKG UPDM (B) pada tahun 20142016. Data yang telah diperoleh dikumpulkan dan ditampilkan dalam bentuk tabel distribusi frekuensi untuk melihat penggunaan bahan resin komposit, GIC dan amalgam di RSGM FKG UPDM (B) Jakarta pada tahun 2014-2016.

\section{HASIL PENELITIAN}

Tabel 1 memperlihatkan distribusi subjek penelitian penggunaan bahan restorasi sebanyak 1322 kasus. Terdapat 502 kasus penggunaan resin komposit (38\%), 195 kasus penggunaan GIC (14,8\%), dan 625 kasus penggunaan amalgam $(47,3 \%)$.

Tabel 2 memperlihatkan distribusi subjek penelitian penggunaan bahan restorasi berdasarkan usia. Subyek terbanyak berusia 17-25 tahun pada penggunaan bahan restorasi amalgam sebesar 263 kasus (19,9\%), sedangkan yang paling sedikit pada usia 5665 tahun pada penggunaan bahan restorasi resin komposit sebesar 11 kasus $(0,8 \%)$.

Tabel 3 memperlihatkan distribusi subjek penelitiaan penggunaan bahan restorasi berdasarkan jenis kelamin. Subjek terbanyak berjenis kelamin perempuan dengan penggunaan bahan restorasi amalgam sebesar 414 kasus $(31,3 \%)$, sedangkan yang paling sedikit ialah berjenis kelamin lakilaki pada penggunaan bahan restorasi GIC sebesar 78 kasus $(5,9 \%)$.

Tabel 4 memperlihatkan distribusi subjek penelitian penggunaan bahan restorasi berdasarkan lokasi restorasi anterior. Subyek terbanyak ialah penggunaan bahan restorasi resin komposit pada klas III sebesar 172 kasus (13\%), sedangkan yang paling sedikit penggunaan bahan restorasi GIC pada klas VI sebesar dua kasus $(0,2 \%)$.

Tabel 5 memperlihatkan distribusi subjek penelitian penggunaan bahan restorasi berdasarkan lokasi restorasi posterior. Subjek terbanyak ialah penggunaan bahan restorasi amalgam pada klas I sebesar 443 kasus $(33,5 \%)$, sedangkan yang paling sedikit penggunaan bahan restorasi resin komposit pada klas VI sebesar 2 kasus $(0,2 \%)$.

Tabel 1. Distribusi frekuensi penggunaan bahan restorasi di RSGM FKG UPDM (B) pada tahun 2014-2016

\begin{tabular}{ccc}
\hline $\begin{array}{c}\text { Bahan } \\
\text { restorasi }\end{array}$ & Frekuensi & $\begin{array}{c}\text { Persentase } \\
(\mathbf{\%})\end{array}$ \\
\hline Resin komposit & 502 & $38 \%$ \\
GIC & 195 & $14,8 \%$ \\
Amalgam & 625 & $47,3 \%$ \\
Total & 1322 & $100 \%$ \\
\hline
\end{tabular}

Tabel 2. Distribusi frekuensi penggunaan bahan restorasi di RSGM FKG UPDM (B) pada tahun 20142016 berdasarkan usia

\begin{tabular}{|c|c|c|c|c|c|c|c|c|}
\hline \multirow{3}{*}{$\begin{array}{c}\text { Usia } \\
\text { (tahun) }\end{array}$} & \multicolumn{6}{|c|}{ Bahan restorasi } & \multicolumn{2}{|c|}{ Total } \\
\hline & \multicolumn{2}{|c|}{ RK } & \multicolumn{2}{|c|}{ GIC } & \multicolumn{2}{|c|}{ Amalgam } & & \\
\hline & Jumlah & $\%$ & Jumlah & $\%$ & Jumlah & $\%$ & Jumlah & $\%$ \\
\hline $17-25$ & 219 & 16,6 & 33 & 2,5 & 263 & 19,9 & 515 & 39 \\
\hline $26-35$ & 104 & 7,9 & 49 & 3,7 & 164 & 12,4 & 317 & 24 \\
\hline $36-45$ & 113 & 8,5 & 47 & 3,6 & 140 & 10,6 & 300 & 22,7 \\
\hline $46-55$ & 55 & 4,2 & 34 & 2,6 & 36 & 2,7 & 125 & 9,5 \\
\hline $56-65$ & 11 & 0,8 & 32 & 2,4 & 22 & 1,7 & 65 & 4,9 \\
\hline Total & 502 & 38 & 195 & 14,8 & 625 & 47,3 & 1322 & 100 \\
\hline
\end{tabular}


Tabel 3. Distribusi frekuensi penggunaan bahan restorasi di RSGM FKG UPDM (B) pada tahun 20142016 berdasarkan jenis kelamin

\begin{tabular}{ccccccccc}
\hline \multirow{2}{*}{$\begin{array}{c}\text { Jenis } \\
\text { kelamin }\end{array}$} & \multicolumn{9}{c}{ Bahan restorasi } & \multicolumn{2}{c}{ Total } \\
\cline { 2 - 7 } & $\begin{array}{c}\text { RK } \\
\text { Jumlah }\end{array}$ & $\boldsymbol{\%}$ & Jumlah & \% & Jumlah & \% & Jumlah & \% \\
\hline Laki-laki & 158 & 12 & 78 & 5,9 & 211 & 16 & 447 & 33,8 \\
Perempuan & 344 & 26 & 117 & 8,9 & 414 & 31,3 & 875 & 66,2 \\
Total & 502 & 38 & 195 & 14,8 & 625 & 47,3 & 1322 & 100 \\
\hline
\end{tabular}

Tabel 4. Distribusi frekuensi penggunaan bahan restorasi di RSGM FKG UPDM (B) pada tahun 20142016 berdasarkan lokasi restorasi anterior

\begin{tabular}{ccccccccc}
\hline \multirow{2}{*}{ Klas } & \multicolumn{9}{c}{ Bahan restorasi } & \multicolumn{2}{c}{ Total } \\
\cline { 2 - 7 } & \multicolumn{2}{c}{ RK } & \multicolumn{2}{c}{ GIC } & \multicolumn{2}{c}{ Amalgam } & & \\
& Jumlah & \% & Jumlah & \% & Jumlah & \% & Jumlah & \% \\
\hline I & 22 & 1,7 & 10 & 0,8 & 0 & 0 & 32 & 2,4 \\
II & 0 & 0 & 0 & 0 & 0 & 0 & 0 & 0 \\
III & 172 & 13 & 44 & 3,3 & 0 & 0 & 216 & 16,3 \\
IV & 39 & 3 & 1 & 0,1 & 2 & 0,2 & 42 & 3,2 \\
V & 40 & 3 & 35 & 2,6 & 0 & 0 & 75 & 5,7 \\
VI & 4 & 0,3 & 2 & 0,2 & 0 & 0 & 6 & 0,5 \\
\hline
\end{tabular}

Tabel 5. Distribusi frekuensi penggunaan bahan restorasi di RSGM FKG UPDM (B) pada tahun 20142016 berdasarkan lokasi restorasi posterior

\begin{tabular}{ccccccccc}
\hline Klas & \multicolumn{4}{c}{ Bahan restorasi } & \multicolumn{2}{c}{ Total } \\
\cline { 2 - 7 } & \multicolumn{2}{c}{ RK } & \multicolumn{2}{c}{ GIC } & \multicolumn{2}{c}{ Amalgam } & & \\
& Jumlah & \% & Jumlah & \% & Jumlah & \% & Jumlah & \% \\
\hline I & 134 & 10,1 & 21 & 1,6 & 443 & 33,5 & 598 & 45,2 \\
II & 52 & 3,9 & 23 & 1,7 & 173 & 13,1 & 248 & 18,8 \\
III & 0 & 0 & 0 & 0 & 0 & 0 & 0 & 0 \\
IV & 0 & 0 & 0 & 0 & 2 & 0 & 0 & 0 \\
V & 37 & 2,8 & 59 & 4,5 & 7 & 0,5 & 103 & 7,8 \\
VI & 2 & 0,2 & 0 & 0 & 0 & 0 & 2 & 0,2 \\
\hline
\end{tabular}

\section{BAHASAN}

Hasil penelitian ini mendapatkan penggunaan bahan restorasi di RSGM FKG UPDM (B) pada tahun 2014-2016 sebanyak 1322 kasus. Perawatan restorasi terbanyak ialah restorasi amalgam (47,3\%) dibandingkan resin komposit (38\%) dan GIC (14,8\%). Hal ini dapat disebabkan karena biaya restorasi amalgam yang relatif murah dan kekuatan restorasi amalgam yang lebih kuat dibandingkan restorasi lainnya dalam menerima tekanan kunyah sehingga amalgam dapat bertahan dalam jangka waktu yang lama di dalam mulut. ${ }^{2,9}$ Penggunaan restorasi amalgam tidak diindikasikan untuk gigi anterior karena menghasilkan estetik. yang tidak bagus dikarenakan warna amalgam sangat berbeda dengan warna gigi asli, yaitu berwarna abu-abu perak. ${ }^{9}$ Hasil penelitian ini berbeda dengan penelitian yang dilakukan di Australia, dimana bahan restorasi yang lebih banyak digunakan yaitu penggunaan restorasi resin komposit $(55 \%)$ dibandingkan restorasi GIC (15\%), dan restorasi 
amalgam $(28 \%) .{ }^{6}$ Hal ini dapat disebabkan karena restorasi resin komposit mempunyai warna dan sifat translusensi seperti gigi asli, sehingga resin komposit memiliki nilai estetik yang lebih baik. ${ }^{11}$

Pada penggunaan bahan restorasi berdasarkan usia, yang paling banyak mendapatkan perawatan ialah kelompok usia 1725 tahun sebesar 515 kasus (39\%) dengan bahan restorasi tertinggi ialah amalgam sebesar 263 kasus $(19,9 \%)$. Hal ini dapat disebabkan karena pada kelompok usia tersebut tidak menjaga dan melaksanakan kebersihan gigi dan mulut yang efektif. ${ }^{12}$ Selain itu dapat disebabkan juga oleh pola makan yang tidak baik dan gaya hidup yang tidak sehat (contohnya merokok). Rokok dapat memengaruhi kesehatan gigi dan mulut dan menimbulkan beberapa kelainan didalam rongga mulut, terutama risiko karies yang sangat tinggi. ${ }^{13}$ Penggunaan restorasi terendah pada kelompok usia 5665 tahun sebesar 65 kasus $(4,9 \%)$, dengan bahan restorasi terendah ialah resin komposit sebanyak 11 kasus $(0,8 \%)$. Hal ini dapat disebabkan karena pada usia ini, pasien telah memiliki kesadaran dalam merawat kebersihan gigi dan mulut. Selain itu, kebanyakan pasien yang memiliki masalah kesehatan gigi dan mulut pada usia ini berupa penyakit periodontal dan karies gigi lebih memilih untuk dilakukan perawatan dengan pencabutan dibandingkan penumpatan gigi dikarenakan mereka tidak ingin dilakukan perawatan yang memakan waktu lama mengingat keadaan mereka sudah lanjut usia. ${ }^{14}$

Penggunaan bahan restorasi berdasarkan jenis kelamin paling banyak pada perempuan sebesar 875 kasus $(66,2 \%)$ sedangkan pada laki-laki sebesar 447 kasus $(33,8 \%)$. Hal ini disebabkan karena perempuan lebih mementingkan penampilan estetiknya. ${ }^{12}$ Erupsi gigi permanen pada perempuan terjadi lebih awal dibandingkan lakilaki sehingga terpapar lebih lama di dalam lingkungan mulut kariogenik yang berakibat terkena karies lebih cepat. Perubahan hormon seperti pada pubertas, mentruasi, dan kehamilan turut berkontribusi terhadap kesehatan gigi dan mulut yang kurang baik sehingga meningkatkan risiko terjadinya karies gigi. Menurut Lukacs et al, ${ }^{15}$ peningkatan karies gigi juga dapat terjadi pada perempuan yang sedang mengonsumsi karbohidrat tinggi dan rendah protein.

Berdasarkan lokasi gigi, penggunaan bahan restorasi yang paling banyak di lokasi posterior ialah amalgam pada tumpatan klas I $(33,5 \%)$ dan klas II $(13,1 \%)$. Hal ini dapat dikarenakan pada gigi posterior, terutama gigi molar bawah memiliki pit and fissure yang cukup banyak sehingga terdapat kesulitan untuk membersihkannya dengan baik. Bagian pit and fissure sulit dijangkau oleh bulu sikat gigi, sehingga memiliki risiko tinggi untuk terkena karies dibandingkan dengan gigi lainnya. ${ }^{16}$ Lokasi restorasi terendah pada anterior dan posterior klas VI. Lokasi ini terdapat pada tepi insisal dan tonjolan oklusal gigi posterior yang disebabkan oleh abrasi, atrisi, ataupun erosi.

\section{SIMPULAN}

Pada penggunaan bahan restorasi di RSGM FKG UPDM (B) tahun 2014-2016 berdasarkan usia, jenis kelamin dan lokasi, yang terbanyak didapatkan ialah penggunaan bahan restorasi amalgam diikuti oleh restorasi komposit pada kelompok usia 1725 tahun, jenis kelamin perempuan, dan lokasi posterior.

Diharapkan penelitian ini dapat memberikan informasi yang bermanfaat bagi mahasiswa pre-klinik maupun mahasiswa klinik seluruh universitas FKG di Indonesia, dokter-dokter gigi dan masyarakat dalam memilih bahan restorasi yang sesuai dengan kebutuhan terutama dalam mementingkan hal estetik,

\section{Konflik Kepentingan}

Penulis menyatakan tidak terdapat konflik kepentingan dalam studi ini.

\section{DAFTAR PUSTAKA}

1. Depkes RI. Riset Kesehatan Dasar. Jakarta: Badan Penelitian dan pengembangan Kesehatan Kementerian Kesehatan Republik Indonesia, 2013; p. 110-8.

2. Kasjono, Subaris H. Intisari Epidemiologi. Jakarta: Mitra Cendikia, 2008. 
3. Reinhart JW, Douglass CW. The need for operative dentistry services: projecting the effects of changing disease patterns. Oper Dent. 1989;14(3):114-8.

4. Garg N, Garg A. Textbook of Operative Dentistry. New Delhi: Jaypee Brothers Medical Publishers, 2010; p. 46, 312.

5. Garg N, Garg A. Textbook of Operative Dentistry. New Delhi: Jaypee Brothers Medical Publishers, 2011; p. 51,166.

6. Pitt FTR. Restorasi gigi. Sumawinata N, alih bahasa. Jakarta: EGC, 1993; p. 1, 61-2, 70.

7. Baum L, Philips RW, Lund MR. Textbook of Operative Dentistry (3rd ed). Tarigan R, alih bahasa. Jakarta: ECG, 1997; p. 1, 19, 30, 41-6, 49, 50-2, 180-1, 265-6, 298, 331.

8. Tyas MJ. Placement and replacement of restoration by selected practicioners. Aust Dent J. 2005;50(2):81-9.

9. Irawan B. Material restorasi direk kedokteran gigi saat ini. J Dent Indones. 2004; 11(1):24-8.

10. Shabrina N, Diansari V, Novita FC. Gambaran penggunaan bahan amalgam, resin komposit, dan glass ionomer cement (GIC) di RSGM Unisyah. J Caninus
Dent. 2016;1(4):9-11.

11. Winanto SS. Kegagalan tumpatan komposit dan berbagai penyebabnya. MI Kedokt Gigi. 1997:35:83-91.

12. Eccless JD, Green RM. Konservasi Gigi (2nd ed). Yuwono L, alih Bahasa. Jakarta: Widya Medika, 1994; p. 21, 37, 39, 40, $74,125$.

13. Warnakulasuriya $S$, Dietrich $T$, Bornstein MM, Peidró EC, Preshaw PM, Walter $\mathrm{C}$, et al. Oral health risks of tobacco use and effects of cessation. Int Dent $\mathrm{J}$. 2010:;60(1):7-30.

14. Ghozali, TD. Kelainan Gigi dan Mulut pada Usia Lanjut. In: Martono H, Pranaka K (editors). Buku Ajar Geriatri (Ilmu Kesehatan Lansia) (4th ed). Jakarta: Balai Penerbit FKUI, 2010; p. 694-706.

15. Lukacs JR, Largaespada LL. Explaining sex differences in dental caries prevalence: saliva, hormones, and 'life history' etiologies." Am J Hum Biol. 2006;2 8(4):540-55.

16. Tulaka B, Wicaksono DA, Tumewu E. Gambaran penggunaan semen ionomer kaca sebagai bahan tumpatan di Rumah Sakit Robert Wolter Mingisidi Manado tahun 2011-2013. e-GiGi. 2014;2(2). 